\title{
$\boldsymbol{E}$

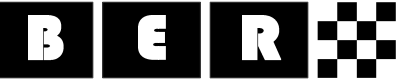

Entrepreneurial Business and Economics Review

2013, Vol. 1, No. 2

\section{The Performance of Socially Responsible Investments}

\author{
Milica Latinovic, Tijana Obradovic
}

\begin{abstract}
A B S T R A C T
Objective: The paper aims to annotate how selection of equity securities can be made by incorporating sustainability into analysis, and to present review of performance evidence of such an investment strategy.

Research Design \& Methods: The authors reviewed the scholarly literature and contemporary research on what constitutes a socially responsible investment, what risks are associated with such an investment, and what evidence of its performance are in different markets. They hypothesized that socially responsible investments underperform non-socially aware investments.
\end{abstract}

Findings: This paper provides review of relevant corporate sustainability indicators used in investment analysis. Also, this paper is trying to present evidence of a link between corporate social responsibility and shareholder value. Research of performance of socially responsible investment equity indices and funds; mostly show that they underperform conventional ones.

Implications \& Recommendations: This paper aims to examine existing findings on socially responsible investing, and to propose modification of corporate strategies accordingly.

Contribution \& Value Added: This paper provides various insights into implications when incorporating environment, social responsibility, and corporate governance into investment strategies.

\begin{tabular}{ll}
\hline $\begin{array}{l}\text { Article type: } \\
\text { Keywords: }\end{array}$ & $\begin{array}{l}\text { literature review } \\
\text { socially responsible investment; ESG approach; equity securities, } \\
\end{array}$ \\
JEL codes: & G11, Q51 \\
\hline \multicolumn{2}{c}{ Published by Centre for Strategic and International Entrepreneurship - Krakow, Poland } \\
\hline
\end{tabular}

\section{Suggested citation:}

Latinovic, M. \& Obradovic, T., (2013). The Performance of Socially Responsible Investments. Entrepreneurial Business and Economics Review, 1(2), pp. 29-40. 


\section{INTRODUCTION}

There are numerous investment strategies that either individual or qualified investors can pursue in selecting an appropriate investment. In recent years investors pay special attention to corporate activities that are socially responsible and some of the investors select investments based on such activities. Corporations make actions that are in accordance with social, environmental and corporate governance principles adopted worldwide. Such actions can be assessed with wide range of indicators, which can be incorporated into investment analysis. When individual or aggregate investment in socially responsible stocks is made, we can assess its performance and determine whether such an investment strategy underperform or outperform conventional investment strategies.

Sustainability represents an emerging business megatrend which has an important role in a creation of a company's competitive strategy. In the last decade, environmental issues were drivers of value creation for various firm stakeholders, and that is due to an increasing competition for natural recourses. Carbon dioxide emissions and water usage (the "externalities") are considered by investors to have large influence on company's performance. Therefore, companies' strategies incorporate, among other things, innovation in energy efficiency, and investments in renewable power sources. Business megatrends have four stages of value creation:

- first stage assumes cost, risks, and waste reduction,

- second stage supposes redesign of business processes,

- third stage delivers revenue growth since new approaches are synergized with corporate strategy,

- fourth stage emerges new business model which increases firms' intangibles, which in return enables long-term competitive advantage (Lubin \& Esty, 2012, p. 1).

With increasing sustainability trend, company can be more competitive if it strategically and systematically incorporates sustainability into its leadership, methods, strategy, management, and reporting. There is no integral framework for measuring sustainability, because data is usually not gathered in a consistent manner. Therefore, companies are developing tools for tracking costs and benefits from sustainable strategies. In order to track companies that deliver sustainable value, analysts need to have sustainable data that can be connected with financial outcomes. Companies that fail to incorporate sustainability into their strategic framework, and more importantly to create value out of it, may lose their competitive position in the market. Depending on the industry sector, some firms will gradually adopt sustainable practices; others will try to be the first. Besides learning what needs to be done, and having clear vision and mission, companies must be sure they have enough of the capabilities for executing sustainable strategies (Lubin \& Esty, 2012, p. 1).

Socially responsible investing is a generic term for ethical and green investing. Since there is a substantial interest in such an investment type, numerous funds with this investment style have been created. Many researchers investigate whether these funds have superior performance than funds with conventional investment style. There is a growth of socially responsible investing in US, and that is due to the rise of investors' requests, legislation, and innovation in new products and funds styles such as focusing on the environmental issues. Therefore, environment, social, and governance (ESG) 
factors are becoming essential for investment analysis, decision making, and portfolio construction. Hence, sustainable investing can be viewed as investment decision making in pursue of superior risk-adjusted returns that integrates long-term ESG factors (Kiymaz, 2012, p. 425).

Organizations incorporate sustainability concepts into their strategies, which can be traced with sustainability indicators. These indicators can be integral part of investment screen. There are various theories and empirical evidence regarding the performance of such an investment strategy. The objective of this paper is to annotate how selection of equity securities can be made by incorporating sustainability into analysis, and to present review of performance evidence of such an investment strategy. In the second part of this paper different hypotheses and their rationale will be presented. Third part presents detailed literature review of the socially responsible investment strategies, their indicators, and its performances. Fourth part brings discussion about the findings presented, and gives concluding remarks along with description of limitations and recommendations for further research.

\section{LITERATURE REVIEW}

There are many different socially responsible investment (SRI) strategies. The two most well-known SRI strategies are Environmental, Social and Governance (ESG)-investing and negative screening. ESG investing represents strategy of including or overweighting companies that have high ESG standards, and removing or underweighting companies with low ESG standards. Negative screening represents a strategy that assumes avoiding investing in "evil" companies in different industries, such as alcohol, tobacco, gambling, and weapons (Guenster, 2012, p. 443). According to Sturmak and Krosinsky (2012) there are different SRI techniques, such as investing in a benchmark index or excluding sinful companies. However, these authors make a clear distinction between different SRI techniques and sustainable investment strategies that have a focus on ESG analysis. When examining performance results from different funds, it is essential to distinguish between studies that are focused on SRI investing and on sustainable investing. Hence, there is no performance deterioration when ESG factors are taken into account in portfolio management (Sturmak \& Krosinsky 2012, p. 393). Scholtens (2014) discusses different responsible strategies, such as sustainability themed investment, Best-in-Class investment selection, norms-based screening, exclusion of holdings from investment universe, integration of ESG factors in financial analysis, engagement and voting on sustainability matters, impact investment. He concludes that it is necessary that academics and responsible investment industry create clear definition and metrics of responsible investment. Institutional investors are the main users of responsible investment strategies, which is due to their need for risk management. Scholtens (2014) observed that in many cases there is no clear connection between responsible investment strategy and responsibility, and the size of responsible investments appears to be overstated.

Funds that incorporate some SRI strategy usually have a two-stage assessment process, when searching for an investment. First stage is the company screening process, in which funds are eliminating companies according to their adopted core principles. Second stage involves company selection based on the extensive list of metrics, usually 
more than 200, which are showing whether there is a historical track of measuring their socially responsible behaviour and more importantly whether the records show they were aligned with their goals (Trevit, 2012, p.11; Hawken, 2012, p. 27). An integrated framework is needed for assessing companies in a second stage of a screen. Such a framework should include financial measures such as return on capital, price to earnings, cash flow along with ESG metrics (Krosinsky, 2012, p. 47).

Table 1. Summary of the performance from several SRI funds

\begin{tabular}{|c|c|c|c|c|}
\hline Fund & $\begin{array}{l}\text { Launch } \\
\text { year }\end{array}$ & Jensen's alpha & Regional focus & Top holdings by sector \\
\hline 1 & 1991 & 29.72 & $\begin{array}{c}\text { Germany } \\
31.07 \%\end{array}$ & Industrial materials $20.83 \%$ \\
\hline 2 & 2007 & 19.12 & $\begin{array}{c}\text { United States } \\
27.02 \% \\
\end{array}$ & Industry Materials $43.44 \%$ \\
\hline 3 & 2008 & 17.66 & $\begin{array}{c}\text { Germany } \\
51.78 \% \\
\end{array}$ & Hardware $33.99 \%$ \\
\hline 4 & 2001 & 19.22 & $\begin{array}{c}\text { United States } \\
42.05 \% \\
\end{array}$ & $\begin{array}{c}\text { Industrial Materials } \\
43.77 \% \\
\end{array}$ \\
\hline 5 & 2000 & $\begin{array}{c}\text { Fund return* } 9.7 \% \\
\text { Benchmark return } 10.3 \%\end{array}$ & $\begin{array}{c}\text { United States } \\
44.6 \%\end{array}$ & $\begin{array}{l}\text { Consumer Discretionary } \\
22.06 \%\end{array}$ \\
\hline 6 & 2009 & $\begin{array}{c}\text { Fund return* } 6.22 \% \\
\text { Benchmark return } 10.43 \%\end{array}$ & $\begin{array}{c}\text { United States } \\
29.2 \%\end{array}$ & $\begin{array}{c}\text { Financials } \\
20.7 \%\end{array}$ \\
\hline 7 & 1988 & $\begin{array}{c}\text { Growth } 24.9 \% \\
\text { Benchmark growth } 27 \%\end{array}$ & $\begin{array}{c}\text { North America } \\
38.9 \% \\
\end{array}$ & Industrials 50.8\% \\
\hline 8 & 2006 & $\begin{array}{c}\text { Fund return* } 31.1 \% \\
\text { Benchmark return } 24.7 \%\end{array}$ & Northern Europe 67.2\% & $\begin{array}{c}\text { Cyclical } \\
34 \%\end{array}$ \\
\hline
\end{tabular}

*Fund return for 3 years

Source: own compilation based on (Boerse Frankfurt, 2013; Triodos Bank, 2013; Aberdeen Global, 2013; Jupiter, 2013; SVM, 2013).

Authors reviewed some publically available sources and documents on the performance of Socially Responsible Funds, and compiled results in Table 1. Different sources report different summary results. It can be seen that SRI funds primarily invest in the US market, and then in the different European markets. Jensen's alpha offers us insight into risk-adjusted performance of the few of the top ecology funds, and fund that invests heavily in Germany, and into Industrial material sector displays superior performance comparing to other ecology funds. Also, return results for few funds can be compared with its benchmark for a 3-year period, and from the table it can be seen that they mostly underperform their benchmarks. Hence, this screening did not provide evidence of SRI funds superior performance. However, this conclusion is based on the very small sample of this industry, yet very representative, since funds displayed in the Table 1 are ones of the best known.

\section{Environmental and Social Metrics}

Different companies and investment funds use vast number of different performance metrics. It would be formidable task to present each of them; instead it would be referred to some of the broad performance areas. Environmental performance metrics are the ones that investors' value the most, because they measure company's efficiency 
to produce goods and services by taking into account value of the resources used and waste generated. They present compliance costs and risks for future market challenges, and they can offer insight into strategic position of a company, and its ability to adapt during turbulent times (Salo, 2012, p. 169).

Increased environmental efficiency can have an effect on cost reduction and profitability enhancement through changes of inputs and outputs in an organization. A company needs to be able to measure and manage resources, waste generated, and emissions created. A company can use different capabilities and take an advantage of environmental innovation opportunities. The capabilities can be grouped under the research and development capabilities, flexibility in its operations, and the ability of a company to strategically position itself. Organizations need to display such capabilities in their operations within a company and along its supply chains. Long-term value of a company can be enhanced if it is capable to be flexible and absorbing changes and effects of demand shifts, the climate change, pollution, and lack of resource. And at the same time, an organization should be able to minimize environmental risk exposure. With better public perception of a company's environmental performance it can experience different benefits. Public perception is created by company's actions and if company fails to meet their expectations regarding environmental performance company can be negatively branded by various stakeholders (Salo, 2012, p. 169).

It is a difficult task to make a connection between social and financial performance, not to mention environmental and governance issues. Labour rights in the company, and its supply chains, and the way workers are treated are very important for corporate performance. Deteriorated public perception of the company can heavily influence its share price. Companies are exposed to a supply chain risk, since it can influence its image through how they choose suppliers, and what raw materials it uses (Viederman, 2012, p. 217). Companies that pay special attention to their workers might also have higher standards for corporate governance and the environment policies (Sturmak \& Krosinsky, 2012 , p. 393). Many authors suggest that human capital is one of the most valuable sources of competitive advantage. Hence, investment in the intangibles can enhance firm value. Jiao (2010) finds a positive relationship between Tobin's $Q$ and stakeholder engagement, where largest impact is observed with employee relations and the environment.

\section{Empirical Results of Performance of SRI}

There are contradictory empirical results regarding the performance of socially responsible investments, looking at the individual and aggregate level. Also, empirical evidence is based on different sources of socially responsible investing performance, such as funds and indices. Di Giuli and Kostovetsky (2014) report that increase in company's CSR rating would result in the negative future stock returns. Furthermore, company's return on assets (ROA) would decrease. Hence, any benefits that stakeholders can experience from social responsibility can have a negative effect on a firm value.

Leite and Ceu Cortez (2014) analysed performance of internationally oriented SRI funds from eight different European markets, and compared them with performance and style of conventional funds. They show evidence that there is no statistically significant 
difference between the performance of international SRI funds and the conventional funds. Also, conventional benchmarks tend to have better explanatory power in explaining SRI returns, than SRI benchmarks do (Leite \& Ceu Cortez, 2014). Renneboog et al. (2008) present summary results for different aspects of socially responsible investing. They reviewed vast empirical evidence on SRI performance, and concluded that investors are willing to accept below optimal financial performance, in order to comply with their own social responsibility values. Socially responsible investors derive non-financial utility from investing in companies with superior CSR, and therefore they are willing to accept lower rate of return. Evidence shows that there is little support of a difference in average performance between SRI and conventional funds. In Continental Europe and Asia-Pacific there is evidence of SRI underperformance. Galema et al. (2008) found that socially responsible investing has an impact on stock returns by lowering the book-to-market ratio, and not generating positive alphas. Nofsinger and Varma (2014) present evidence that there is an asymmetry in returns during period of crises and non-crises. Socially responsible mutual funds outperform conventional mutual funds, in the periods of market crises, but underperform in the non-crises periods. This asymmetric return pattern is found in mutual funds that focus on ESG factors.

Ortas et al. (2012) examined the financial performance of SRI equity index - the Brazilian Corporate Sustainability Index. They found that in the bullish market periods, investors can pursue their ethical investment strategies in the emerging markets (Ortas et al., 2012). The growth of SRI enhanced financing of developments and improvements in cleaner production methods, and moved companies closer to corporate sustainability. Hence, investments in cleaner production vary across different geographical regions. The reasons for such differences results from the differences in available capital in a particular region, existence of suitable finance mechanisms, and the level of development of banking system. Ortas et al. (2013) presented information of outcomes of integration of ESG factors for cleaner production into investment strategies in Asia Pacific region. They have analysed performance of Dow Jones Sustainability Asia Pacific index compared to the Dow Jones Global Total Stock Market Index (conventional index) and they have found that sustainability index did not underperform the conventional one, when looking at risk-adjusted returns. Furthermore, sustainability index was less risky than conventional index for the period in question (Ortas et al., 2013). Oh et al. (2013) have examined how financial sector firms and their ratings with the Dow Jones Sustainability World Index change. They have found that even leading financial institutions do not employ proactive practices regarding socially responsible investment and shareholder activism. The empirical findings from previously discussed papers are displayed in Table 2. 
Table 2. Summary of existing empirical evidence of SRI performance

\begin{tabular}{|c|c|c|c|c|c|}
\hline Authors & Year & $\begin{array}{l}\text { Market } \\
\text { studied }\end{array}$ & Sample size & Period & Empirical evidence \\
\hline $\begin{array}{l}\text { Di Giuli and } \\
\text { Kostovetsky }\end{array}$ & 2014 & USA & $\begin{array}{l}3000 \text { publicly traded } \\
\text { companies }\end{array}$ & 2003-2009 & $\begin{array}{l}\text { Firm value would decrease if CSR } \\
\text { rating increases }\end{array}$ \\
\hline $\begin{array}{l}\text { Leite and } \\
\text { Ceu Cortez }\end{array}$ & 2014 & Europe & $\begin{array}{l}54 \text { SRI funds/145 } \\
\text { Conventional funds }\end{array}$ & $2000-2008$ & $\begin{array}{l}\text { No statistically significant } \\
\text { difference between the } \\
\text { performance of international SRI } \\
\text { funds and the conventional funds }\end{array}$ \\
\hline $\begin{array}{l}\text { Renneboog } \\
\text { et al. }\end{array}$ & 2008 & $\begin{array}{l}\text { Reviewe } \\
\text { markets }\end{array}$ & $\begin{array}{l}\text { d studies that investigated } \\
\text { and different time periods }\end{array}$ & different & $\begin{array}{l}\text { There is little support of a } \\
\text { difference in average performance } \\
\text { between SRI and conventional } \\
\text { funds }\end{array}$ \\
\hline Galema et al. & 2008 & USA & $\begin{array}{l}\text { All stocks from Russell } \\
2000\end{array}$ & \begin{tabular}{|l|}
$1992-2006$ \\
$1991-2004$
\end{tabular} & $\begin{array}{l}\text { Socially responsible investing is } \\
\text { lowering book-to-market ratio, and } \\
\text { does not generate positive alphas }\end{array}$ \\
\hline $\begin{array}{l}\text { Nofsinger } \\
\text { and Varma }\end{array}$ & 2014 & USA & 240 & $2000-2011$ & $\begin{array}{l}\text { In the period of market crunch SRI } \\
\text { mutual funds outperform } \\
\text { conventional mutual funds, but } \\
\text { underperform in the non-crises } \\
\text { periods }\end{array}$ \\
\hline Ortas et al. & 2012 & Brazil & $\begin{array}{l}1067 \text { continuous daily } \\
\text { excess returns of } \mathrm{BSCl}\end{array}$ & $2005-2010$ & $\begin{array}{l}\text { Brazilian Corporate Sustainability } \\
\text { Index outperformed in the bullish } \\
\text { market periods }\end{array}$ \\
\hline Ortas et al. & 2013 & $\begin{array}{l}\text { Asia- } \\
\text { Pacific }\end{array}$ & $\begin{array}{l}2043 \text { continuously } \\
\text { compounded daily excess } \\
\text { returns of SRI and } \\
\text { conventional DJ indices }\end{array}$ & $2003-2011$ & $\begin{array}{l}\text { Sustainability index did not } \\
\text { underperform, and was less risky } \\
\text { than conventional index }\end{array}$ \\
\hline Oh et al. & 2013 & \multicolumn{3}{|c|}{ Overview of CSR in financial sector } & 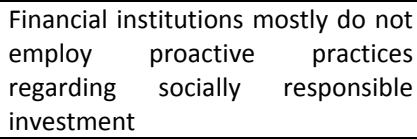 \\
\hline
\end{tabular}

Source: own compilation based on articles indicated above.

\section{MATERIAL AND METHODS}

Sustainable development is considered to be the development that enables present and future generations to meet their needs. This kind of development has three dimensions: environmental, social, and economic, which needs to be balanced in order to maintain an organization, community, nation, or economy. Sustainability is a value set. Corporations that share sustainability philosophy can, and must materially contribute to the melioration of the society. Generally, organizations must balance their needs with much broader society interests. Corporate social responsibility (CSR) may be defined as one element of a corporate strategy that concentrates on sustainability. Hence, it defines and executes processes that enable the protection of the interests of external stakeholders, while organization pursues its goals (Kiymaz, 2012, p. 425).

From the early days of their development, investment funds that practiced socially responsible investing were focused on ethical issues and environmental concerns in their assessment practices. That led to negative screening practices, which assumed that companies that produce and distribute alcohol, and tobacco for example, are excluded from the investment universe. However, recent practice tends make an investment selection based on valuation of wide array of environmental, social, health and safety, 
and governance practice (Soyka, 2012). Traditional finance is based on the assumption that investors are only concerned with expected returns on their investments. On the other hand, socially responsible investors care about their financial returns, but they want those returns to be made from companies that are in alignment with their religious, political, and ethical values (Guenster, 2012, p. 443). Modern portfolio theory states that diversification decreases portfolios total risk. Negative screening strategy reduces potential investment universe, and therefore lower risk-adjusted return should be expected (Kiymaz, 2012, p. 425).

There are different hypotheses of performance of socially responsible funds. First hypothesis, which can be found in the literature, states that risk-adjusted expected returns of socially responsible and conventional funds are equal. Performance of socially responsible funds does not include value added with inclusion of such activities. The second hypothesis states that expected returns of socially responsible funds are lower than those of conventional ones. Rationale for such a statement lies in the shift of the mean-variance frontier. Since socially responsible funds screen potential investments in a non-random manner, they do not use full diversification potential; hence risk-return trade-off is less desirable than a conventional fund can offer. Reduced investment universe and diversification can create additional risks and increase volatility which can influence their returns. The third hypothesis states that expected returns of socially responsible funds are higher than expected returns of conventional funds. Proponents of socially responsible investments argue that socially responsible investors would place pressure on firms not conducting sustainable strategy (Kiymaz, 2012, p. 425). We support hypothesis that socially responsible investments underperform non-socially aware investments.

\section{CONCLUSIONS}

This paper reviews literature regarding socially responsible investments. Different researches stress the need for an integral definition of socially responsible investment, and also for an integral framework of indicators. This paper made a distinction between concepts of sustainability, corporate social responsibility, socially responsible investing, and investing based on the ESG factors.

Data that present sustainability efforts of a company are reported by a company itself. There are different regulatory frameworks around the world, and different reporting standards. In order to track and value sustainability, consistent data is needed. Furthermore, there is limited amount of data available, since companies track sustainability only for a limited period of time. Also, new sustainable business models have not emerged yet, hence it is difficult to create integrated performance indicator framework. No integrated sustainable performance system presents a limitation to a performance analysis of socially responsible investment strategies. Formulation of such a system, which is going to be in accordance with business model developed in the stage four of sustainability trend development, should be a direction for further researches.

Socially responsible investment strategy decreases potential investment set, and hence investors do not merit from the full diversification. Sustainable investing strategy or ESG strategy, cannot yet exploit its full potential since sustainability is still in its infancy, did not reach stage four in its development. There are still not enough 
managerial capabilities and developed business models, to generate superior returns to a socially responsible investor compared to a traditional investor.

Companies face a large number of different risks, and among them are environmental risk, compliance risk, supply chain risk. By creating suitable business model, and doing extensive research about potential suppliers, all this risks should be addressed, and decreased.

Empirical evidence of a performance of a socially responsible funds support two hypotheses, that there is no statistically significant difference in returns generated by socially responsible funds and conventional funds, and that they were underperforming. Empirical evidence at the individual corporate level shows that company value is decreasing, when pursuing corporate social responsible strategy. At the index level, results support outperformance hypothesis of a SRI strategy, during bullish market periods or for a specific period analysed in emerging markets. Since performance results are different, depending on which source for a social responsible investment performance is used, we cannot make a general conclusion. Further research is needed at the corporate level examining returns and value of socially responsible investing, and also at the aggregate market level.

\section{REFERENCES}

Aberdeen Global, 2013, Available from: http://www.aberdeenglobal.com/doc.nsf/Lit/FactsheetGlobalResponsibleWorldEquity (accessed November 2013).

Boerse Frankfurt, 2013, Available from: http://www.boerse-frankfurt.de/en/sustainable+securites (accessed December 2013).

Galema, R., Plantinga, A. \& Scholtens, B., 2008, 'The stocks at stake: Return and risk in socially responsible investment', Journal of Banking \& Finance, vol. 32, iss. 12, pp. 2646-2654.

Di Giuli, A. \& Kostovetsky, L., 2014, 'Are red or blue companies more likely to go green? Politics and corporate social responsibility', Journal of Financial Economics, Vol. 111, no. 1, pp. 158-180. Available from: http://dx.doi.org/10.1016/j.jfineco.2013.10.002 (accessed December 2013).

Guenster, N., 2012, 'Performance Implications of SR Investing: Past versus Future'. In K H. Baker \& J. R. Nofsinger (Eds),Socially Responsible Finance and Investing: Financial Institutions, Corporations, Investors, and Activities, John Wiley and Sons, Hoboken, pp. 443-454.

Hawken, P., 2012, 'A Predictor of Performance'. In C. Krosinsky, N. Robins \& S. Viederman (Eds), Evolutions in Sustainable Investing: Strategies, Funds, and Thought Leadership, John Wiley and Sons, Hoboken, pp. 27-34.

Jiao, Y., 2010, 'Stakeholder Welfare and Firm Value', Journal of Banking and Finance, vol. 34, iss. 10, pp. 2549-2561.

Jupiter, 2013, Jupiter Online, Available from: < http://www.jupiteronline.com/en-GB/Individualinvestors/Funds-and-prices> (accessed November 2013).

Kiymaz, H., 2012, 'SRI Mutual Fund and Index Performance'. In K. H. Baker \& J. R. Nofsinger (Eds), Socially Responsible Finance and Investing: Financial Institutions, Corporations, Investors, and Activities, John Wiley and Sons, Hoboken, pp. 425-442.

Krosinsky, C., 2012, 'Further Context'. In C. Krosinsky, N. Robins \& S. Viederman (Eds), Evolutions in Sustainable Investing: Strategies, Funds, and Thought Leadership, John Wiley and Sons, Hoboken, pp. 47-52. 
Leite, P. \& Ceu Cortez, M., 2014, 'Style and performance of international socially responsible funds in Europe', Research in International Business and Finance, vol. 30, pp. 248- 267.

Lubin, D. A. \& Esty, D. C., 2012, 'The Sustainability Imperative'. In C. Krosinsky, N. Robins \& S. Viederman (Eds), Evolutions in Sustainable Investing: Strategies, Funds, and Thought Leadership, John Wiley and Sons, Hoboken, pp. 1-10.

Nofsinger, J. \& Varma, A., 2014, 'Socially responsible funds and market crises', Journal of Banking and Finance. Article in press, Available from <http://dx.doi.org/10.1016/ j.jbankfin > (accessed December 2013).

Oh, C.H., Park, J-H. \& Ghauri, P.N., 2013, 'Doing right, investing right: Socially responsible investing and shareholder activism in the financial sector', Business Horizons, vol. 56, iss.6, pp.703714, Available from: <http://dx.doi.org/10.1016/j.bushor> (accessed December 2013).

Ortas, E., Burritt, R.L. \& Moneva, J.M., 2013, 'Socially Responsible Investment and cleaner production in the Asia Pacific: does it pay to be good?', Journal of Cleaner Production, vol. 52, pp. 272-280. Available from: http://dx.doi.org/10.1016/j.jclepro (accessed December 2013).

Ortas, E., Moneva, J.M. \& Salvador, M., 2012, 'Does socially responsible investment equity indexes in emerging markets pay off? Evidence from Brazil', Emerging Markets Review, vol. 13, iss.4, pp. 581-597.

Renneboog, L., Horst, J.T. \& Zhang, C., 2008, 'Socially responsible investments: Institutional aspects, performance, and investor behavior', Journal of Banking \& Finance, vol. 32, iss. 9, pp. 1723-1742.

Salo, J., 2012, 'Environmental Metrics'. In C. Krosinsky, N. Robins \& S. Viederman (Eds), Evolutions in Sustainable Investing: Strategies, Funds, and Thought Leadership, John Wiley and Sons, Hoboken, pp. 169-180.

Scholtens, B., 2014, 'Indicators of Responsible Investing', Ecological Indicators, vol. 36, pp. 382385.

Soyka, P.A., 2012, Creating a Sustainable Organization: Approaches for Enhancing Corporate Value Through Sustainability, Pearson Education, Inc., New Jersey.

Sturmark, B. \& Krosinsky, C., 2012, 'On Performance'. In C. Krosinsky, N. Robins \& S. Viederman (Eds), Evolutions in Sustainable Investing: Strategies, Funds, and Thought Leadership, John Wiley and Sons, Hoboken, pp. 393-400.

SVM, 2013, SVM Asset Management, Available from:<http://www.svmonline.co.uk /Navigate.aspx/Private-Investor/1/Investment-Funds/All-Europe-SRI-Fund> laccessed December 2013).

Trevit, M.L., 2012, 'Jupiter Ecology'. In C. Krosinsky, N. Robins \& S. Viederman (Eds), Evolutions in Sustainable Investing: Strategies, Funds, and Thought Leadership, John Wiley and Sons, Hoboken, pp. 11-26.

Triodos Bank, 2013, Available from: <http://www.triodos.co.uk/en/personal/ethicalinvestments/socially-responsible-investments/sustainable-equity-fund/about-the-fund> (accessed December 2013).

Viederman, D., 2012, 'The Silent "S" in ESG'. In C. Krosinsky, N. Robins \& S. Viederman (Eds), Evolutions in Sustainable Investing: Strategies, Funds, and Thought Leadership, John Wiley and Sons, Hoboken, pp. 217-220. 


\section{Authors}

\section{Milica Latinovic}

Currently employed at the Faculty of Organizational Sciences of the University of Belgrade (Serbia), at the Department of Financial Management and Accounting, pursuing her PhD degree there.

\section{Tijana Obradovic}

Working for the Department of Financial Management and Accounting at the Faculty of Organizational Sciences of the University of Belgrade (Serbia), where at the same time she is a PhD candidate.

\section{Correspondence to:}

Milica Latinovic (PhD Student)

University of Belgrade

Faculty of Organizational Sciences

Department of Financial Management and Accounting

Jove llica 154, Belgrade, Serbia

latinovicm@fon.bg.ac.rs 
